\title{
High casein kinase 1 epsilon levels are correlated with better prognosis in subsets of patients with breast cancer
}

\author{
Jose Luis Lopez-Guerra ${ }^{1,2}$, Eva M. Verdugo-Sivianes ${ }^{1}$, Daniel Otero-Albiol' ${ }^{1}$, Begoña \\ Vieites $^{3}$, Maria J. Ortiz-Gordillo${ }^{2}$, Jose M. De León ${ }^{4}$, Juan M. Praena-Fernandez ${ }^{5}$, \\ Juan J. Marin ${ }^{1,6}$ and Amancio Carnero ${ }^{1,7}$ \\ ${ }^{1}$ Instituto de Biomedicina de Sevilla (IBIS/HUVR/CSIC/Universidad de Sevilla), Seville, Spain \\ 2 Department of Radiation Oncology, University Hospital Virgen del Rocío, Seville, Spain \\ ${ }^{3}$ Department of Pathology, University Hospital Virgen Del Rocío, Seville, Spain \\ ${ }^{4}$ Unidad Funcional de Patología Mamaria, University Hospital Virgen Del Rocío, Seville, Spain \\ ${ }^{5}$ Methodology Unit- Fundación Pública Andaluza para la Gestión de la Investigación en Salud de Sevilla, Virgen del Rocío \\ University Hospital, Seville, Spain \\ ${ }^{6}$ Department of Preventive Medicine and Public Health, Seville University, Seville, Spain \\ ${ }^{7}$ Consejo Superior de Investigaciones Científicas, Seville, Spain \\ Correspondence to: Amancio Carnero, email: acarnero-ibis@us.es
}

Keywords: breast cancer, casein kinase 1 epsilon (CK $1 \varepsilon$ ), relapse, disease-free survival, outcome

Received: May 18, $2015 \quad$ Accepted: June 28, 2015

Published: July 13, 2015

This is an open-access article distributed under the terms of the Creative Commons Attribution License, which permits unrestricted use, distribution, and reproduction in any medium, provided the original author and source are credited.

\section{ABSTRACT}

Reliable biological markers that predict breast cancer (BC) outcomes after multidisciplinary therapy have not been fully elucidated. We investigated the association between casein kinase 1 epsilon (CK1ع) and the risk of recurrence in patients with BC. Using 168 available tumor samples from patients with BC treated with surgery +/- chemo(radio)therapy, we scored the CK1ع expression as high ( $\geq 1.5)$ or low $(<1.5)$ using an immunohistochemical method. Kaplan-Meier analysis was performed to assess the risk of relapse, and Cox proportional hazards analyses were utilized to evaluate the effect of CK1 1 expression on this risk. The median age at diagnosis was 60 years (range 35-96). A total of $58 \%$ of the patients underwent breast conservation surgery, while $42 \%$ underwent mastectomy. Adjuvant chemotherapy and radiation therapy were administered in $101(60 \%)$ and 137 cases $(82 \%)$, respectively. Relapse was observed in 24 patients (14\%). Multivariate analysis found high expression of CK1 1 to be associated with a statistically significant higher diseasefree survival (DFS) in BC patients with wild-type p53 (Hazard ratio [HR] $=0.33 ; 95 \%$ $C I, 0.12-0.91 ; P=0.018$ ) or poor histological differentiation ( $[\mathrm{HR}]=0.34 ; 95 \% \mathrm{CI}$, $0.12-0.94 ; P=0.039)$ or in those without adjuvant chemotherapy ( $[\mathrm{HR}]=0.11 ; 95 \%$ CI, 0.01-0.97; $P=0.006$ ). Our data indicate that CK1 $\varepsilon$ expression is associated with DFS in BC patients with wild-type p53 or poor histological differentiation or in those without adjuvant chemotherapy and thus may serve as a predictor of recurrence in these subsets of patients.

\section{INTRODUCTION}

Breast cancer is the second leading cause of cancer death in women, responsible for approximately $3 \%$ of deaths.. Death rates from breast cancer have been declining since approximately 1989(American Cancer society, http://www.cancer.org) believed to be the result of earlier detection through screening and increased awareness, as well as improved treatment. Depending on the stage of the tumor, local or systemic therapies are administered. Patients who have no detectable cancer after surgery are often given adjuvant therapy to help prevent the cancer from relapsing. In the setting of multidisciplinary therapies for breast cancer (BC), relapses are a severe event, leading 
to hospitalizations, second surgeries, or the initiation of systemic treatments affecting the survival outcome. Both systemic therapy, such as chemotherapy, hormone therapy and targeted therapy, and radiation can be used as adjuvant therapy. Most, but not all, patients benefit from adjuvant therapy. How much the patient might benefit depends on the stage and characteristics of the cancer and the type of surgery. Recent studies $[1,2]$ have shown that specific receptors predict relapse in $\mathrm{BC}$ patients and have been used as targets to improve the outcome. For example, a review of $119 \mathrm{BC}$ patients receiving trastuzumab for human epidermal growth factor receptor-2 (HER2)positive metastatic disease, indicated that those receiving taxanes with trastuzumab had a median overall survival that was significantly longer compared to other first-line partners [2].

However, beyond these tumor-staging endpoints, there is no reliable information that can predict which tumors treated with adjuvant chemotherapy are more likely to relapse or to obtain a benefit. Although some clinical and pathological parameters have been included in tumor response models to guide therapy and prevent relapse, the predictive value of these parameters is limited, as demonstrated by the observation that patients with similar characteristics often have contrasting tumor responses. One way to improve on these models would be to include biological markers representing tumor tissue sensitivity

Casein kinase 1 (CK1) is a member of a family of serine/threonine protein kinases. CK1 kinases exist in at least seven isoforms $(\alpha, \beta, \gamma 1-3, \delta$ and $\varepsilon)$ in mammals [35].CK1 kinases phosphorylate various substrates that play vital roles in diverse physiological processes such as DNA repair, cell cycle progression, cytokinesis, differentiation and apoptosis [4-6]. CK1-epsilon (CK1E) is a protein product of the $C S N K 1 E$ gene. CK1 $1 \varepsilon$ has been shown to be essential in regulating cell division and tumor growth in human pancreatic and colon adenocarcinoma cells and in salivary gland cancer by phosphorylating key proteins in the Wnt signaling pathway [7-10].

Changes in CK1E expression and activity, as well as the occurrence of mutations within the coding region of $\mathrm{CK} 1 \varepsilon$, have been reported in various cancers, including breast and ovarian cancers [4-6, 11, 12]. Our study investigates whether differences in CK1 $1 \varepsilon$ expression are associated with clinicopathological and molecular parameters in patients with $\mathrm{BC}$ who receive surgery +/- chemo(radio)therapy. This information could be determined before therapy and incorporated into tumor tissue response models to plan the treatment for individual patients.

\section{RESULTS}

\section{Overexpression of active CK1s enhances growth of tumor cells in vitro and sensitivity to UV exposure}

We recovered the full-length CSNKIE gene from one gain-of-function genetic screening event to identify genes that are able to alter the cellular response to physiological signals and provide a selective advantage once tumorigenesis has begun [13]. The CK1 $\varepsilon$ promotes oncogenic transformation in multiple cell types, including
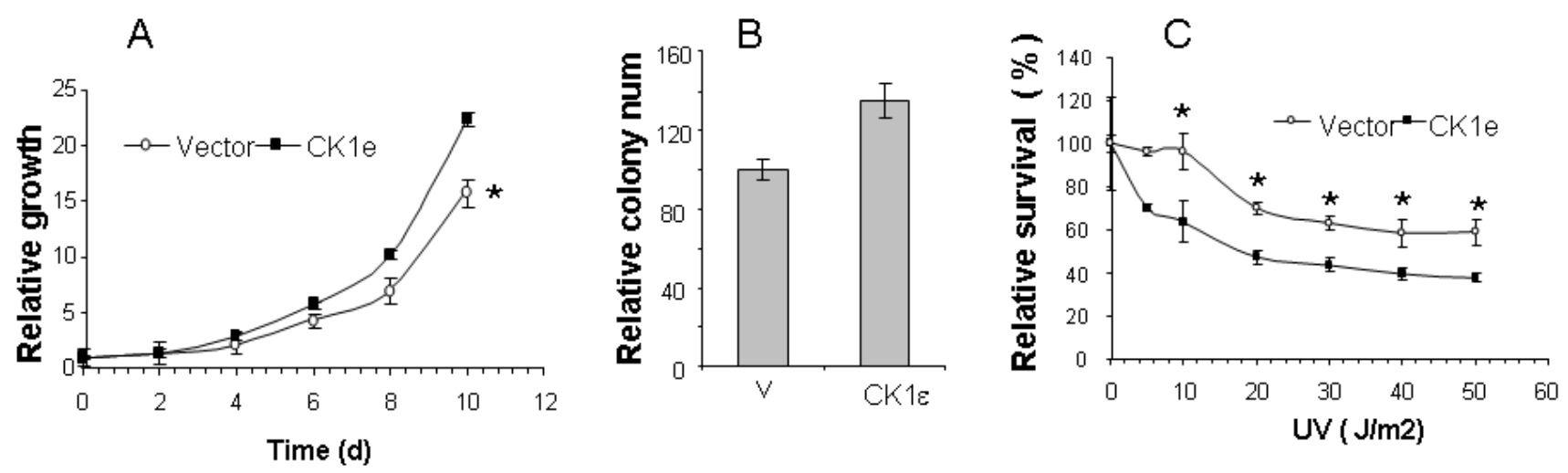

Figure 1: Overexpression of active CK1 $1 \varepsilon$ enhances growth of tumor cells in vitro and sensitivity to UV exposure. A. Active CK1 $\varepsilon$ increased the growth of mammary tumor cells. Growth curve of parental T47D cells expressing an empty vector (vector) or myristoylated CK1 $\varepsilon$ expressing mass culture $(\mathrm{CK} 1 \varepsilon)$ in T47D. Values are expressed as the percentage of cell growth. The data are presented as the mean of triplicate samples; bars, \pm SD. B. Colony assay of T47D cells expressing an empty vector (vector) or myristoylated CK1 $\varepsilon$ expressing mass culture (CK1E) in T47D. Values are represented as the percentage of number of colonies. Parental T47D control cells represent $100 \%$ of cell growth. The data are presented as the mean of triplicate samples; bars, \pm SD. C. Response to UV irradiation in

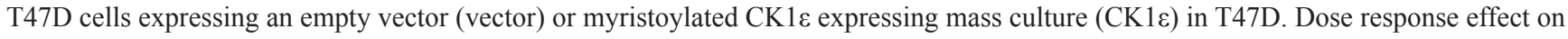
cells $48 \mathrm{hrs}$ after UV irradiation. Values are expressed as the percentage of live cells. Untreated control cells represent $100 \%$ of the cells. The Student $\mathrm{T}$ test was used to compare the statistical significance of the differences among the survival curves of parental cells versus the clones. $*=p<0.05$ 
Table 1: Patient characteristics

\begin{tabular}{|c|c|}
\hline Characteristics & No. of Patients $(\%)$ \\
\hline & $(N=168)$ \\
\hline \multicolumn{2}{|l|}{ Age (years) } \\
\hline Median (range) & $60(35$ to 96$)$ \\
\hline \multicolumn{2}{|l|}{ Type } \\
\hline Invasive ductal carcinoma & $151(90)$ \\
\hline Invasive lobular carcinoma & $8(5)$ \\
\hline Mucinous carcinoma & $4(2)$ \\
\hline Metaplastic carcinoma & $1(0.5)$ \\
\hline Micropapillary carcinoma & $3(2)$ \\
\hline Medullary carcinoma & $1(0.5)$ \\
\hline \multicolumn{2}{|l|}{ Grade $(\mathrm{N}=168)$} \\
\hline Well differentiated & $23(14)$ \\
\hline Moderately differentiated & $59(35)$ \\
\hline Poorly differentiated & $84(50)$ \\
\hline Undifferentiated & $2(1)$ \\
\hline \multicolumn{2}{|l|}{ Estrogen receptors } \\
\hline Yes & $133(79)$ \\
\hline No & $35(21)$ \\
\hline \multicolumn{2}{|l|}{ Progesterone receptors } \\
\hline Yes & $119(71)$ \\
\hline No & $49(29)$ \\
\hline \multicolumn{2}{|c|}{ Human epidermal growth factor receptor } \\
\hline Yes & $11(6)$ \\
\hline No & $157(94)$ \\
\hline \multicolumn{2}{|l|}{$\mathrm{Ki}-67$} \\
\hline Median (range) & $18(5-70)$ \\
\hline \multicolumn{2}{|l|}{ Stage } \\
\hline $\mathrm{I}$ & $63(37)$ \\
\hline II & $68(41)$ \\
\hline III/IV & $37(22)$ \\
\hline \multicolumn{2}{|l|}{ Chemotherapy } \\
\hline Yes & $101(60)$ \\
\hline No & $67(40)$ \\
\hline \multicolumn{2}{|l|}{ Type of surgery } \\
\hline Conservative & $97(58)$ \\
\hline Mastectomy & $71(42)$ \\
\hline \multicolumn{2}{|l|}{ Hormone therapy } \\
\hline Yes & $125(75)$ \\
\hline No & $43(25)$ \\
\hline \multicolumn{2}{|l|}{ Radiation therapy } \\
\hline Yes & $137(82)$ \\
\hline No & $31(18)$ \\
\hline \multicolumn{2}{|l|}{ CK1E } \\
\hline High expression $(\geq 1.5)$ & $96(57)$ \\
\hline Low expression $(<1.5)$ & $72(43)$ \\
\hline \multicolumn{2}{|l|}{ Luminal A } \\
\hline Yes & $120(71)$ \\
\hline No & $48(29)$ \\
\hline \multicolumn{2}{|l|}{ Luminal B } \\
\hline Yes & $13(8)$ \\
\hline
\end{tabular}




\begin{tabular}{|l|l|}
\hline No & $155(92)$ \\
\hline Luminal HER2 & \\
\hline Yes & $11(7)$ \\
\hline No & $157(93)$ \\
\hline Triple-negative & \\
\hline Yes & $24(14)$ \\
\hline No & $144(86)$ \\
\hline Recurrence & \\
\hline Distant & $22(13)$ \\
\hline Loco-regional & $4(2)$ \\
\hline Status & \\
\hline Alive & $145(86)$ \\
\hline Death & $23(14)$ \\
\hline Follow-up (months) & \\
\hline Median (range) & $70(10-77)$ \\
\hline
\end{tabular}

immortal non-tumoral human mammary epithelial cells HEMCs [14]; however, transformation only occurs if myristoylated (active) CK1 $1 \varepsilon$ is expressed because wildtype CK1 $1 \varepsilon$ does not seem to contribute to tumorigenesis [14]. Therefore, we tested whether myristoylated CK1 $1 \varepsilon$ induced an enhancement of tumorigenic properties in

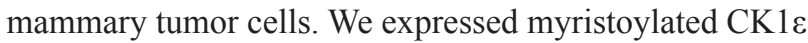
(see M\&M) or empty vectors in ductal adenocarcinoma T47D cells. We found that myristoylated CK1 $\varepsilon$ induced a significant increase in growth and colony forming efficiency in these cells (Figure 1A and 1B). Furthermore, we subjected these cells to different doses of UV irradiation as a surrogate for radiotherapy. In this setting, the expression of myristoylated CK1 $1 \varepsilon$ induced some sensitivity to irradiation (Figure 1C).

\section{CK1E levels in breast tumors}

To determine the relevance of CK1 $1 \varepsilon$ in human mammary tumors we analyzed tumor samples from 168 $\mathrm{BC}$ patients (Table 1). The median age was 60 years (a range of 35-96 years). There were 63 patients with stage I, 68 with stage II and 37 with stage III/IV. Twenty-three tumors were well differentiated, 59 were moderately differentiated, and 84 were poorly differentiated. The median follow-up was 70 months with a median diseasefree survival (DFS) of 65 months (range, 1-76 months). The five-year overall survival (OS) rate was $88 \%$. Fiftyeight percent of the patients underwent conservative breast surgery, while forty-two percent were treated by mastectomy. Adjuvant therapy was administered according to individual considerations. Chemotherapy and/or radiation therapy were delivered in $60 \%$ and $82 \%$ of patients, respectively. Relapse was observed in 24 patients (14\%).

CK1 $\varepsilon$ expression, mainly cytoplasmic (see Figure 2 ), was considered low $(<1.5)$ in 72 patients and high $(\geq 1.5)$ in 96 patients (Figure 2), indicating that $57 \%$ of the patients showed high levels of CK1ع. The staining was homogeneous for most samples, with some samples with some minimal heterogeneity in signal intensity among tumor cells. Those with positive nodal status had a narrower $\mathrm{CK} 1 \varepsilon$ expression range than those without nodal involvement $(P=0.025$, Figure 3B). However, there was no difference in CK1 $1 \varepsilon$ expression according to stage $(P=0.099$, Figure $3 \mathrm{C})$ or molecular subtype $(P=$ 0.648 , Figure 3D). Similar findings were observed when $\mathrm{CK} 1 \varepsilon$ expression was evaluated with regard to hormonal receptors $(P=0.478$ and 0.373 , Figures $3 \mathrm{E}$ and $3 \mathrm{~F})$.

\section{High CK1 1 levels correlated with better prognosis in subset of patients with breast tumors}

The five-year DFS rate was $81 \%$ for the group with low CK1 $1 \varepsilon$ expression and $92 \%$ for the group with higher expression ( $P=0.107$, Figure 4A). Although not significant, there is a trend towards the relevance of levels of CK1 $\varepsilon$ in DFS in mammary tumor patients. A similar trend was observed for the total survival rate $(P=0.116$, Figure 4B).

The correlation between the expression levels of CK1 1 and clinical parameters is summarized in Table 2. Univariate Cox proportional hazard analyses of the data for DFS showed that higher CK1 $1 \varepsilon$ expression is associated with an increase in DFS in BC patients with negative (wild type) p53 ( $\mathrm{HR}=0.32,95 \% \mathrm{CI}, 0.12$ to $0.86, P=0.018$; Table 2), poor histologic differentiation $(\mathrm{HR}=0.36,95 \% \mathrm{CI}, 0.13$ to $0.98, P=0.039)$, Ki67 $\geq$ median $(\mathrm{HR}=0.36,95 \% \mathrm{CI}, 0.13$ to $1.03, P=0.047)$, or a triple-negative subtype (HR $=0.42,95 \% \mathrm{CI}, 0.16$ to $1.08, P=0.018$ ) (Figure 5). This effect was virtually unchanged after adjusting for other confusing factors (i.e., pathologic stage) by multivariate analysis in $\mathrm{BC}$ patients with negative p53 (HR $=0.33,95 \% \mathrm{CI}, 0.12$ to $0.91, P=$ $0.032)$ or poor histologic differentiation ( $\mathrm{HR}=0.32,95 \%$ CI, 0.12 to $0.94, P=0.032$ ). 


\section{A}
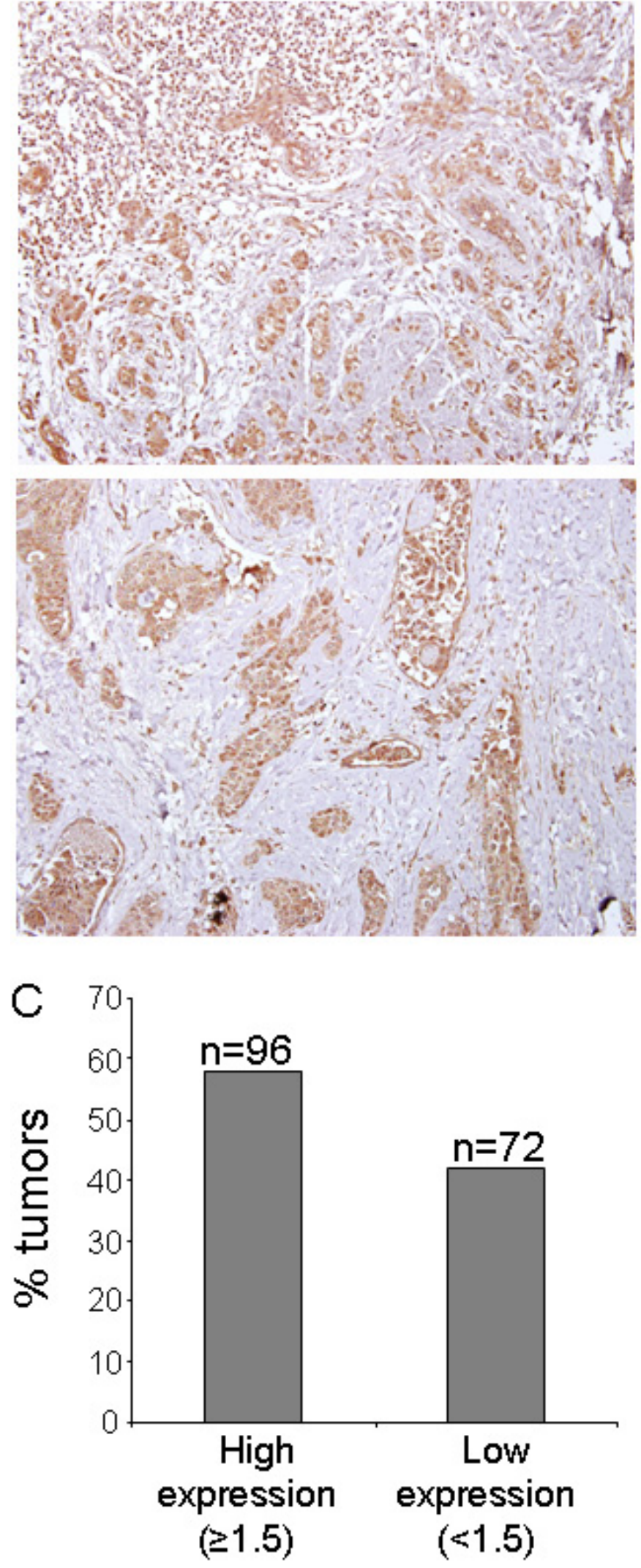

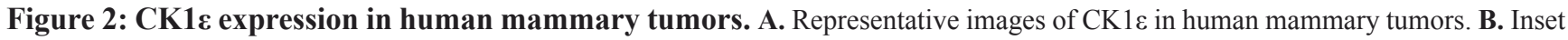
amplification of tumor staining. C. Graph showing the percentage of tumors with high (score $>1.5)$ or low $($ score $<1.5)$ levels of $\mathrm{CK} 1 \varepsilon$. 

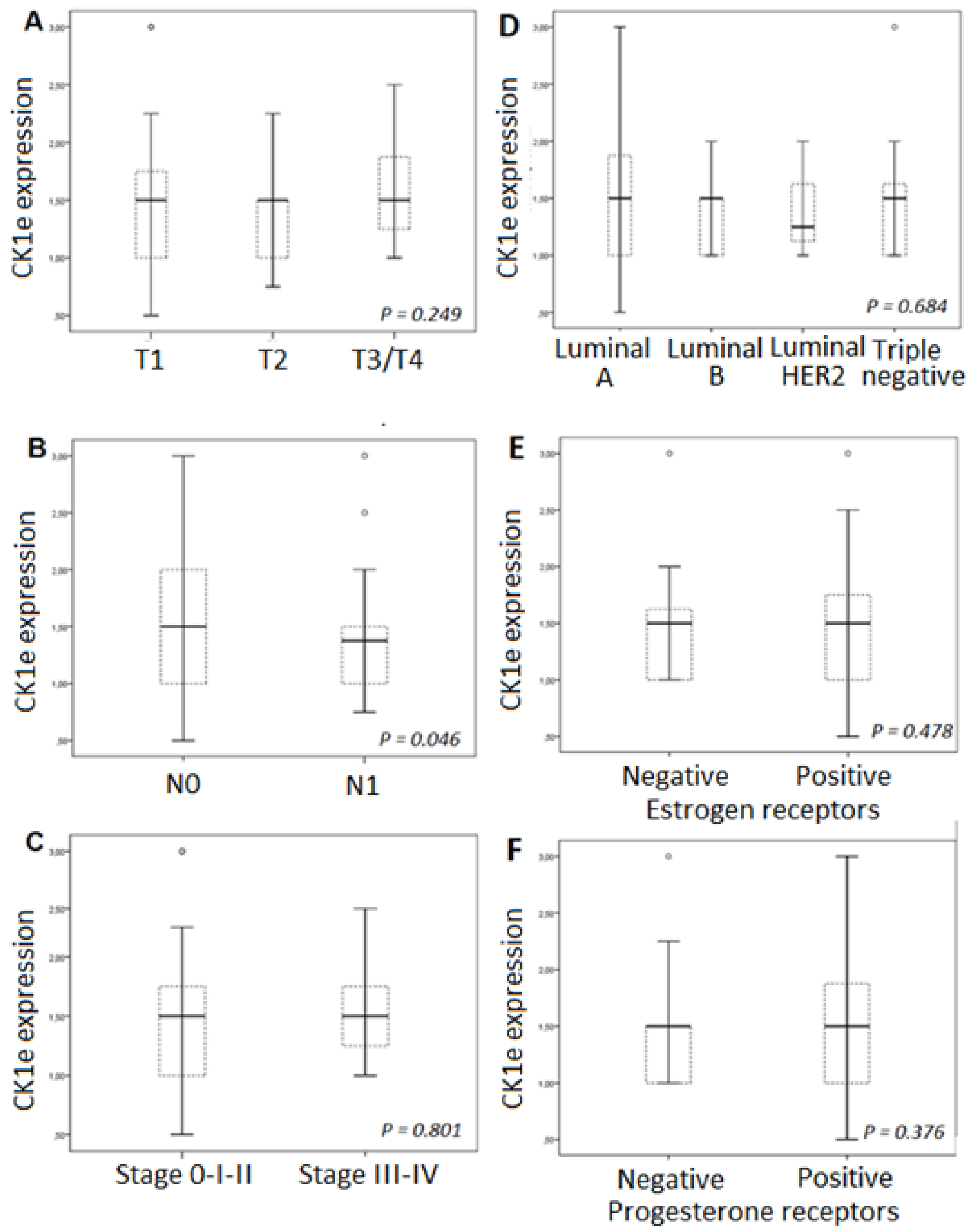

Figure 3: CK1E expression according to: A. molecular subtypes, B. estrogen receptors, and C. progesterone receptors; D. T classification, E. N status, and F. tumor stage. 
Table 2: Univariate and multivariate analyses of associations between clinicopathologic factors and disease-free survival (DFS) in patients with significant/marginal association found between CK1E and DFS in the univariate analysis. *Number of patients carrying the category/ number of patients with relapse. $†$ Variables shown are those that had statistical significance. $\dagger \dagger$ Multivariate analyses in this table were adjusted for those variables that had statistical significance by univariate analysis.

\begin{tabular}{|c|c|c|c|c|c|c|c|c|}
\hline \multirow[t]{2}{*}{ Subset } & Characteristic & \multicolumn{4}{|c|}{ Univariate Analysis† } & \multicolumn{3}{|c|}{ Multivariate Analysis $\dagger^{\dagger}$} \\
\hline & & No.* & HR & $\mathrm{CI}$ & $\mathrm{P}$ & HR & $\mathrm{CI}$ & $P$ \\
\hline \multirow[t]{12}{*}{$\begin{array}{l}\text { Patients with } \\
\text { negative p53 }\end{array}$} & $\begin{array}{l}\text { Histologic } \\
\text { differentiation }\end{array}$ & & & & & & & \\
\hline & Well/Moderate & $63 / 6$ & & & & & & \\
\hline & Poor & $53 / 12$ & 2.67 & $1.01-7.12$ & 0.049 & 2.65 & $0.97-7.19$ & 0.056 \\
\hline & Pathologic Stage & & & & & & & \\
\hline & $\mathrm{I} / \mathrm{II}$ & $96 / 10$ & & & & & & \\
\hline & III/IV & $20 / 8$ & 4.44 & $1.74-11.28$ & 0.002 & 2.94 & $1.11-7.80$ & 0.030 \\
\hline & Surgical procedure & & & & & & & \\
\hline & Lumpectomy & $67 / 6$ & & & & & & \\
\hline & Mastectomy & $49 / 12$ & 2.95 & $1.11-7.87$ & 0.031 & 2.03 & $0.73-5.59$ & 0.170 \\
\hline & CK1E & & & & & & & \\
\hline & $<1,5$ & $48 / 12$ & & & & & & \\
\hline & $\geq 1,5$ & $68 / 6$ & 0,32 & $0,12-0,86$ & 0,025 & 0.32 & $0.12-0.91$ & 0.032 \\
\hline \multirow{9}{*}{$\begin{array}{l}\text { Patients with } \\
\text { age } \geq \text { median }\end{array}$} & Pathologic Stage & & & & & & & \\
\hline & $\mathrm{I} / \mathrm{II}$ & $68 / 8$ & & & & & & \\
\hline & III/IV & $16 / 6$ & 3.07 & $1.09-8.65$ & 0.033 & 1.45 & $0.49-4.30$ & 0.499 \\
\hline & Surgical procedure & & & & & & & \\
\hline & Lumpectomy & $47 / 3$ & & & & & & \\
\hline & Mastectomy & $37 / 12$ & 5.83 & $1.64-20.72$ & 0.006 & 5.22 & $1.39-19.54$ & 0.014 \\
\hline & CK1E & & & & & & & \\
\hline & $<1,5$ & $40 / 11$ & & & & & & \\
\hline & $\geq 1,5$ & $44 / 4$ & 0.32 & $0.10-1.01$ & 0.050 & 0.33 & $0.10-1.05$ & 0.060 \\
\hline \multirow{9}{*}{$\begin{array}{l}\text { Patients } \\
\text { with poor } \\
\text { histologic } \\
\text { differentiation }\end{array}$} & Pathologic Stage & & & & & & & \\
\hline & I/II & $62 / 7$ & & & & & & \\
\hline & III/IV & $24 / 10$ & 4.09 & $1.55-10.75$ & 0.004 & 2.78 & $1.00-7.74$ & 0.50 \\
\hline & Surgical procedure & & & & & & & \\
\hline & Lumpectomy & $42 / 4$ & & & & & & \\
\hline & Mastectomy & $44 / 13$ & 3.39 & $1.10-10.42$ & 0.033 & 2.75 & $0.83-9.06$ & 0.095 \\
\hline & CK1E & & & & & & & \\
\hline & $<1,5$ & $36 / 11$ & & & & & & \\
\hline & $\geq 1,5$ & $50 / 6$ & 0.36 & $0.13-0.98$ & 0.048 & 0.34 & $0.12-0.94$ & 0.038 \\
\hline
\end{tabular}




\begin{tabular}{|c|c|c|c|c|c|c|c|c|}
\hline \multirow{6}{*}{$\begin{array}{l}\text { Patients with } \\
\text { Ki67 } \geq \text { median }\end{array}$} & Pathologic Stage & & & & & & & \\
\hline & $\mathrm{I} / \mathrm{II}$ & $50 / 7$ & & & & & & \\
\hline & $\mathrm{III} / \mathrm{IV}$ & $20 / 8$ & 3.09 & $1.12-8.54$ & 0.029 & 2.88 & 1.04-7.98 & 0.041 \\
\hline & CK1E & & & & & & & \\
\hline & $<1,5$ & $27 / 9$ & & & & & & \\
\hline & $\geq 1,5$ & $43 / 6$ & 0.36 & 0.13-1.03 & 0.057 & 0.39 & 0.14-1.11 & 0.080 \\
\hline \multirow{9}{*}{$\begin{array}{l}\text { Patients } \\
\text { without } \\
\text { chemotherapy }\end{array}$} & Pathologic Stage & & & & & & & \\
\hline & $\mathrm{I} / \mathrm{II}$ & $57 / 4$ & & & & & & \\
\hline & $\mathrm{III} / \mathrm{IV}$ & $10 / 5$ & 8.01 & $2.13-30.03$ & 0.002 & 4.05 & $1.01-16.19$ & 0.0437 \\
\hline & Ki67 (\%) & & & & & & & \\
\hline & $<$ median & $45 / 3$ & & & & & & \\
\hline & $\geq$ median & $20 / 6$ & 5.21 & $1.30-20.85$ & 0.020 & 4.45 & 1.06-18.61 & 0.041 \\
\hline & CK1E & & & & & & & \\
\hline & $<1,5$ & $30 / 8$ & & & & & & \\
\hline & $\geq 1,5$ & $37 / 1$ & 0.09 & $0.01-0.77$ & 0.028 & 0.12 & $0.01-0.97$ & 0.048 \\
\hline \multirow{12}{*}{$\begin{array}{l}\text { Patients } \\
\text { without triple- } \\
\text { negative } \\
\text { breast cancer }\end{array}$} & \begin{tabular}{|l|} 
Histologic \\
differentiation
\end{tabular} & & & & & & & \\
\hline & Well/Moderate & $79 / 6$ & & & & & & \\
\hline & Poor & $65 / 13$ & 2.99 & $1.13-7.87$ & 0.027 & 2.51 & $0.93-6.75$ & 0.068 \\
\hline & Pathologic Stage & & & & & & & \\
\hline & $\mathrm{I} / \mathrm{II}$ & $110 / 10$ & & & & & & \\
\hline & III/IV & $34 / 9$ & 3.17 & $1.29-7.82$ & 0.012 & 1.52 & $0.58-3.97$ & 0.388 \\
\hline & Surgical procedure & & & & & & & \\
\hline & Lumpectomy & $84 / 4$ & & & & & & \\
\hline & Mastectomy & $61 / 15$ & 5.65 & 1.87-17.04 & 0.002 & 4.36 & 1.36-13.95 & 0.013 \\
\hline & CK1E & & & & & & & \\
\hline & $<1,5$ & $63 / 12$ & & & & & & \\
\hline & $\geq 1,5$ & $81 / 7$ & 0.42 & $0.16-1.08$ & 0.075 & 0.39 & $0.15-1.01$ & 0.051 \\
\hline
\end{tabular}

We also analyzed the DFS according to CK1 $1 \varepsilon$ expression and age. For patients who had an age $>60$ years, those with a higher CK1 $1 \varepsilon$ expression had a lower incidence of relapse than those patients with lower expression $(P=0.039)$ (Figure 6B). However, this difference was not significant in younger patients (Figure 6A). Finally, we evaluated the association between CK1 $1 \varepsilon$ expression and $\mathrm{BC}$ patients treated with or without adjuvant chemotherapy. Strikingly, those patients who did not undergo adjuvant chemotherapy and had a higher CK1 $\varepsilon$ expression had a higher DFS in the multivariate analyses $(P=0.006)$. However, this difference was not significant in patients who underwent chemotherapy (Figures 6C and 6D).

\section{DISCUSSION}

Our study demonstrates that some subsets of BC patients with high CK1ع expression levels have a lower risk of relapse andhigher DFS. Therefore, increased CK1 $1 \varepsilon$ expression is greatly associated with better outcome and might be considered a good survival factor. This is consistent with reports showing that oral squamous cell carcinoma [15] and BC [16] patients who had an increase in CK1 $1 \varepsilon$ expression had a considerably better outcome than patients who had lower CK1 $1 \varepsilon$ expression. Our data are also in agreement with those of Richter et al [17] for colorectal cancer patients, where high expression of CK $1 \varepsilon$ was significantly correlated with survival in a cohort of 122 patients. On the contrary, in ovarian cancer, it has been shown that expression of CK1 $1 \varepsilon$ is related to poor survival [10]. Fuja et al [16] showed that CK1\& levels were reduced in poorly differentiated tumors and overexpressed in more benign ductal cell carcinoma in situ, thus correlating decreased levels of CK1 $1 \varepsilon$ with more aggressive tumors. They hypothesized that the poor prognosis of low levels 
of $\mathrm{CK} 1 \varepsilon$ was more related to the downregulation of $\mathrm{CK} 1 \varepsilon$ in tumor tissue, which was also observed in head and neck squamous tumors. We also observed higher levels of $\mathrm{CK} 1 \varepsilon$ in noninvasive $\mathrm{BC}$ than in infiltrating $\mathrm{BC}$ (Figure 3A); however, the levels are similar among invasive $\mathrm{BC}$ of different $\mathrm{T}$ stages. The fact that $\mathrm{CK} 1 \varepsilon$ is a predictive marker independent from tumor differentiation, stage, molecular type, hormone receptors, p53 and Ki67 indicates that the better prognosis of high CK1 $1 \varepsilon$ levels is not related to its tumor suppressor properties. We suggest that higher levels of $\mathrm{CK} 1 \varepsilon$ activity may sensitize tumors to radiation therapy, perhaps by increasing the proliferation rate, which will correlate with our data (Figure 1) and those reporting CK1 $1 \varepsilon$ as an oncogene $[5,6,14,17,18]$. The latter is also supported by the development of CK1 $1 \varepsilon$ inhibitors that reduced the proliferation index and tumor burden $[14,17,18]$ and may sensitize tumor cells to other therapies [4-6]. However, in light of our results of better prognosis in the absence of chemotherapy (Figure 6D), these CK $1 \varepsilon$ inhibitors should be used very cautiously for treating different tumors and with the different therapeutic modalities.

Additionally, we were able to identify subgroups of $\mathrm{BC}$ patients with marginal statistically significant association between higher $\mathrm{CK} 1 \varepsilon$ expression and an increase in DFS, which are those having an age $\geq$ median, $\mathrm{Ki} 67 \geq$ median, or wild-type p53 or those without triplenegative breast cancer. Of particular interest were the highly significant differences in DFS according to the CK $1 \varepsilon$ expression when patients were stratified according to treatment with adjuvant chemotherapy. This observation implies that while $\mathrm{BC}$ patients receiving adjuvant chemotherapy have similar outcomes regardless of the CK1 $1 \varepsilon$ expression, the absence of this complementary therapy could significantly affect the DFS if the tumor has high levels of $\mathrm{CK} 1 \varepsilon$, and therefore, we can expect a prevalence of relapses for patients with low CK1 $1 \varepsilon$ expression. Because this information could be obtained before the initiation of chemotherapy, this additional information could potentially be used as a predictive biomarker to tailor therapy when attempting to devise chemotherapy for an individual patient who has low CK1 $1 \varepsilon$ expression. Additional functional studies are required to understand this association.

CK1 $\varepsilon$ has been shown to be a positive regulator of both the canonical Wnt/ $\beta$-catenin pathway $[5,19-21]$ and noncanonical Wnt pathways $[22,23]$. WNT, fibroblast growth factor, Notch, Hedgehog, transforming growth factor and the bone morphogenetic protein signaling network are implicated in the maintenance of tissue homeostasis by regulating the self-renewal of normal stem cells as well as the proliferation or differentiation of progenitor cells [24-26]. Disruption of the stem cell signaling network leads to carcinogenesis. In addition, CK1 also suppressed Forkhead O transcription factor (FOXO) activity [27]. Inactivation of FOXO proteins is associated with tumorigenesis, including $\mathrm{BC}$, prostate cancer, glioblastoma, rhabdomyosarcoma and leukemia [28]. Shin et al [29] showed that CK1e plays a critical role in cancer cell proliferation by controlling mRNA translation. CK1e interacted with and phosphorylated 4EBP1 at two novel sites, T41 and T50, which were essential for 4E-BP1 inactivation along with increased mRNA translation and cell proliferation. In summary, it has been

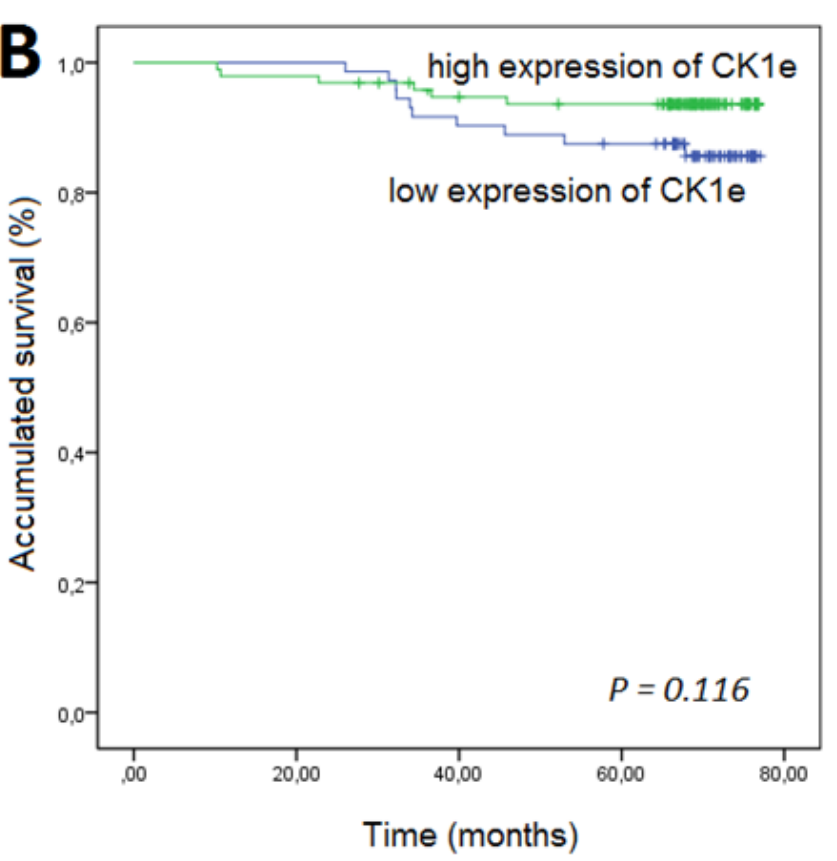

Figure 4: Kaplan-Meier survival curves for breast cancer patients who were classified with either low or high CK1E expression. High CK1E expression was associated (log-rank) with better A. disease-free survival and B. overall survival. 
shown that CK1 1 plays a role as a tumor suppressor or oncogene in carcinogenesis. Divergences in pathological diagnosis, tumor size, histologic grade, stage, anatomic location of the tumor, neoadjuvant therapy, etc. among studies may in part explain this apparently contradictory result. CK1 $1 \varepsilon$ triggers a diverse array of responses, depending on the genetic makeup and environment of the target cells.

Besides the constraints inherent in any retrospective analysis, our study had several limitations. First, to limit the scope and thus increase the feasibility of this analysis, we selected and analyzed CK1 $1 \varepsilon$ expression alone, and we did not find a significant correlation with relapse for the entire group. Occurrence of relapse is likely to involve a complex interplay between several molecular processes that were not analyzed in this study. Second, although we were able to establish strong statistical associations between clinical/pathological factors and the risk of relapse, we did not explore the biological mechanism by which the selected protein led to recurrence in patients
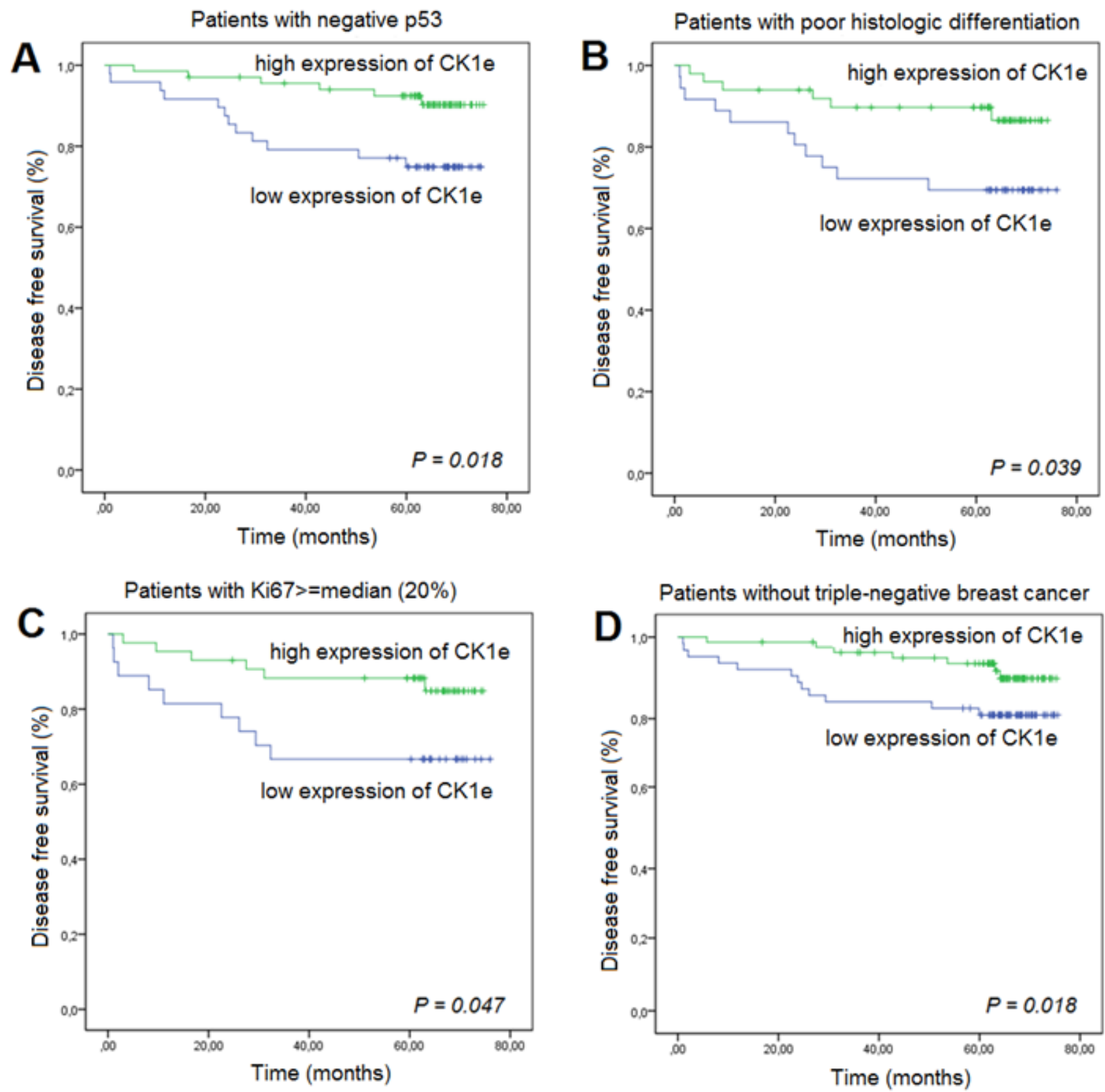

Figure 5: Kaplan-Meier survival curves for breast cancer patients who were classified with either low or high CK1E expression. High CK1E expression was associated (log-rank) with better prognosis as measured by disease-free survival in patients with A. negative p53, B. poor histologic differentiation, C. Ki67 $\geq$ median, or D. triple-negative breast cancer. 
with BC. This issue is the topic of ongoing assessment at our institution. In summary, our goal was to identify a biomarker that predicts relapse risk for patients with $\mathrm{BC}$ prior to the initiation of therapy. The results from this study demonstrated that low $\mathrm{CK} 1 \varepsilon$ expression was associated with poor DFS in patients with BC with negative $\mathrm{p} 53$ or poor histologic differentiation or without adjuvant chemotherapy, suggesting the possibility of using this biomarker as a predictive factor for relapse. However, to fully evaluate the significance of the expression of these
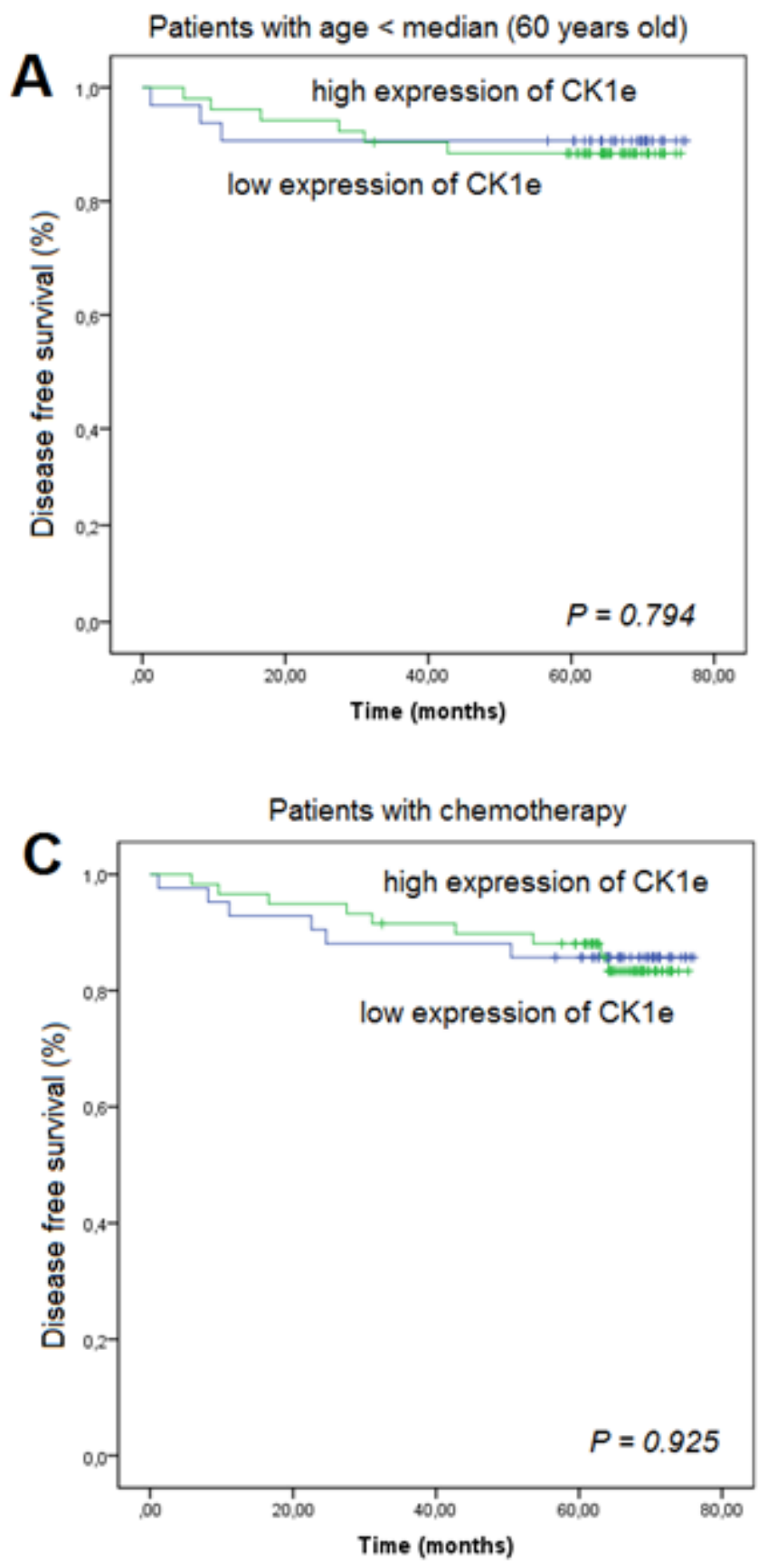

protein kinases, we will need to both validate the results of this study in a prospective cohort of patients and to understand the effect of this protein on tumor relapse, both of which are currently under investigation.
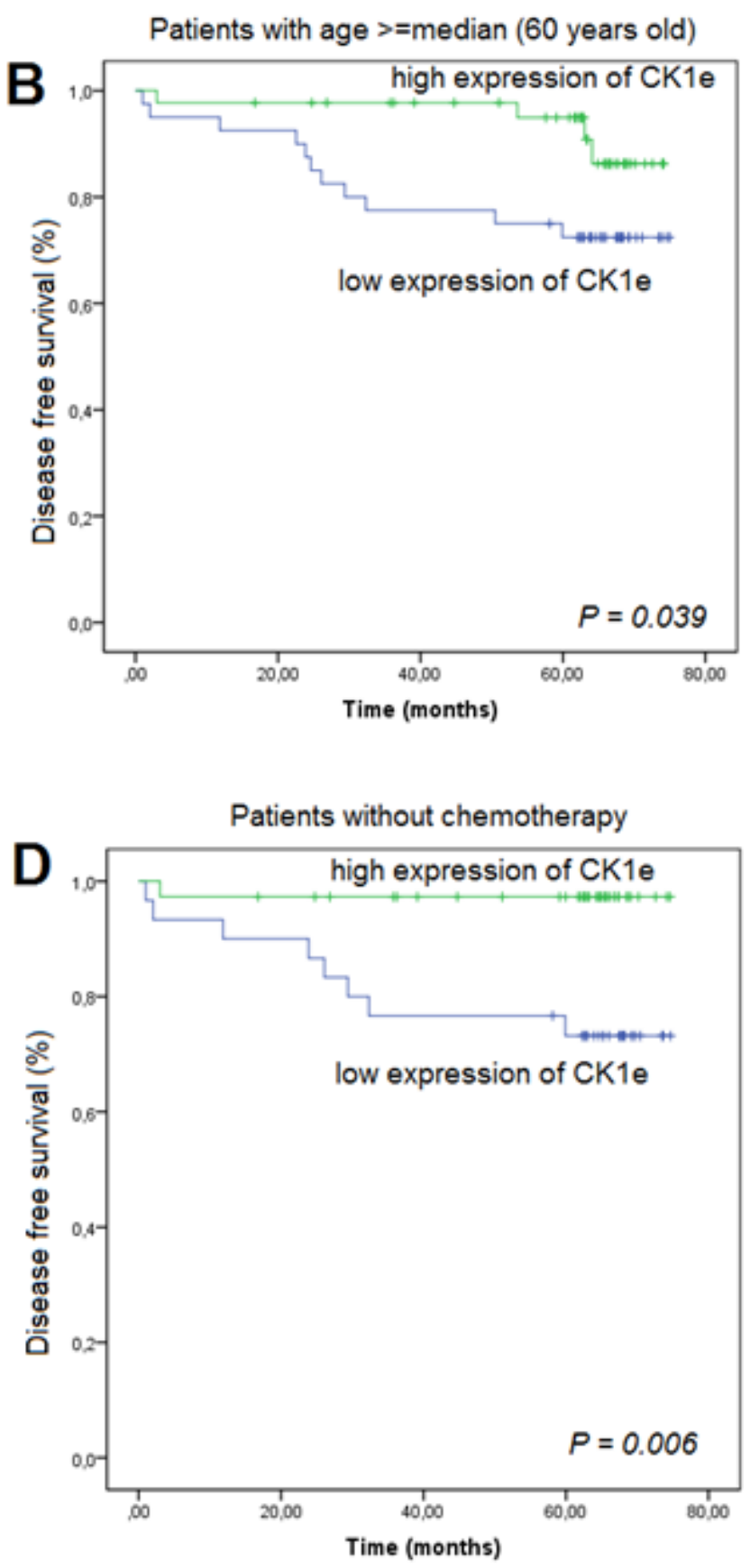

Figure 6: Kaplan-Meier survival curves for breast cancer patients who were classified with either low or high CK1E expression. High CK1E expression was associated (log-rank) with prognosis as measured by disease-free survival in patients according to age, A. below the median, or B. equal to or above the median .C. adjuvant chemotherapy given or D. no adjuvant chemotherapy. 


\section{MATERIALS AND METHODS}

\section{Patient population}

This study was performed in accordance with standard ethical procedures dictated by Spanish law (Ley de Investigación Orgánica Biomédica, 14 July 2007) and was approved by the ethics committee of the Hospital Virgen del Rocío and the Fundación Pública Andaluza para la Gestión de la Investigación en Salud de Sevilla (FISEVI), Spain. Written informed consent was obtained from all patients, and all clinical analyses were conducted in accordance with the principles of the Helsinki Declaration.

Beginning in 2006, 339 patients with a diagnosis of $\mathrm{BC}$ were treated with surgery $+/$ - chemo(radio)therapy at our institution. The inclusion criteria were tumor tissue available, no prior thoracic surgery or chemo(radio) therapy, no prior or concurrent other malignancy and no bilateral disease. Ultimately, 168 patients met these criteria. Disease in all cases was staged according to the 2009 (7th) edition of the American Joint Committee on Cancer staging system [30]. The patient data are described in Table 1.

Patients were evaluated at 2 and 6 months and then every year after the completion of treatment. At each visit, a history was taken and a physical examination was performed. Mammography and/or computed axial tomography/magnetic resonance imaging (i.e., after mastectomy) were performed at 6 months after therapy and then yearly. Bone scans or positron emission tomography (PET) scans were performed if clinically indicated.

\section{Tissue microarray immunohistochemistry}

Immunohistochemical studies were performed on breast tumor specimens in a tissue microarray (TMA). The TMA was constructed as previously described [31, 32] and was processed for immunostaining and development according to the vendor's instructions. Two cores per tumor sample were included in the TMA. Incubations with primary antibodies (Anti-CK1epsilon: ab70110 from Abcam; anti-p53: p53 FL 393 (sc-6243) from Santa Cruz) were performed for $40 \mathrm{~min}$. We quantified the levels of CK1 1 by immunostaining and by doubleblind observation (two independent observers without knowledge of the clinical features of the samples) where the following discrete values were assigned: 0 , no CK1 $1 \varepsilon$ expression; 1 , weak expression; 2 , clear strong expression, and 3 , very strong expression. Both blind values were averaged for each core sample, and both core sample values were averaged. CK1 $1 \varepsilon$ expression determined by the immunohistochemical method was scored as high $(\geq 1.5)$ or low $(<1.5)$.

\section{Cell lines and experiments}

The T47D cell line was obtained from the ECACC commercial repository at the beginning of this work. No further authentication was conducted by the authors.

For the myristoylated version of the CK1 $1 \varepsilon$ protein, the human Src myristoylation sequence was introduced at the 5' end of the CSNK1E CDNA (in a manner similar to that described in [33]).

Cells were cultured by following the experimental procedures in the ATCC cell line data sheet. Retroviral vectors and gene transfers were performed as previously described $[32,34]$. Growth curves and colony formation assays were conducted as previously described $[32,34]$.

\section{Statistical analysis}

Data were analyzed using SPSS (version 19.0) statistical software. Potential risk factors were assessed in univariate analyses using the Cox proportional hazards model. Because of the possible confounding effects of clinical factors on survival, associations found to be statistically significant $(P<0.05)$ or with a marginal trend $(P<0.1)$ in the univariate analysis were adjusted for those variables that had statistical significance on the univariate analysis. The time to end point development was calculated from the surgery date; patients not experiencing the end point were censored at the date of last contact.

\section{ACKNOWLEDGMENTS}

The authors thank the donors and the Andalusian Public Health System Biobank (ISCIII-Red de Biobancos RD12/0036/0017) for the human specimens used in this study.

\section{FUNDING}

The AC lab was supported by grants from the Spanish Ministry of Economy and Competitivity, Plan Nacional de I+D+I 2008-2011, ISCIII (Fis: PI12/00137, RTICC: RD12/0036/0028) co-funded by FEDER from Regional Development European Funds (European Union), Consejeria de Ciencia e Innovacion (CTS-6844 and CTS-1848) and Consejeria de Salud of the Junta de Andalucia (PI-0135-2010 and PI-0306-2012). This work has also been possible thanks to the Plan Estatal de I+D+i 2013-2016, Grant PIE13/0004 co-funded by the ISCIII and FEDER funds.

\section{CONFLICTS OF INTERESTS}

The authors declare no conflict of interest. 


\section{REFERENCES}

1. Rayson D, Lutes S, Walsh G, Sellon M, Colwell B, Dorreen M, Drucker A, Jeyakumar A, Younis T. Trastuzumab beyond progression for HER2 positive metastatic breast cancer: progression-free survival on first-line therapy predicts overall survival impact. Breast J. 2014; 20: 408413.

2. Horimoto Y, Arakawa A, Harada-Shoji N, Sonoue H, Yoshida Y, Himuro T, Igari F, Tokuda E, Mamat O, Tanabe M, Hino O, Saito M. Low FOXA1 expression predicts good response to neo-adjuvant chemotherapy resulting in good outcomes for luminal HER2-negative breast cancer cases. Br J Cancer. 2015; 112: 345-351.

3. Knippschild U, Gocht A, Wolff S, Huber N, Lohler J, Stoter $\mathrm{M}$. The casein kinase 1 family: participation in multiple cellular processes in eukaryotes. Cell Signal. 2005; 17: 675689.

4. Knippschild U, Kruger M, Richter J, Xu P, Garcia-Reyes B, Peifer C, Halekotte J, Bakulev V, Bischof J. The CK1 Family: Contribution to Cellular Stress Response and Its Role in Carcinogenesis. Front Oncol. 2014; 4: 96.

5. Price MA. CKI, there's more than one: casein kinase I family members in Wnt and Hedgehog signaling. Genes Dev. 2006; 20: 399-410.

6. Schittek B, Sinnberg T. Biological functions of casein kinase 1 isoforms and putative roles in tumorigenesis. Mol Cancer. 2014; 13: 231

7. Frierson HF, Jr., El-Naggar AK, Welsh JB, Sapinoso LM, Su AI, Cheng J, Saku T, Moskaluk CA, Hampton GM. Large scale molecular analysis identifies genes with altered expression in salivary adenoid cystic carcinoma. Am J Pathol. 2002; 161: 1315-1323.

8. Peters JM, McKay RM, McKay JP, Graff JM. Casein kinase I transduces Wnt signals. Nature. 1999; 401: 345-350.

9. Polakis P. The many ways of Wnt in cancer. Curr Opin Genet Dev. 2007; 17: 45-51.

10. Rodriguez N, Yang J, Hasselblatt K, Liu S, Zhou Y, RauhHain JA, Ng SK, Choi PW, Fong WP, Agar NY, Welch WR, Berkowitz RS, Ng SW. Casein kinase I epsilon interacts with mitochondrial proteins for the growth and survival of human ovarian cancer cells. EMBO molecular medicine. 2012; 4: 952-963.

11. Modak C, Chai J. Potential of casein kinase I in digestive cancer screening. World journal of gastrointestinal oncology. 2009; 1: 26-33.

12. Yang YH, Chen CH, Chang JS, Lin CC, Cheng TC, Shieh TY. Incidence rates of oral cancer and oral pre-cancerous lesions in a 6-year follow-up study of a Taiwanese aboriginal community. J Oral Pathol Med. 2005; 34: 596601 .

13. Guijarro MV, Leal JF, Fominaya J, Blanco-Aparicio C, Alonso S, Lleonart M, Castellvi J, Ruiz L, Ramon YCS, Carnero A. MAP17 overexpression is a common characteristic of carcinomas. Carcinogenesis. 2007; 28: 1646-1652.

14. Kim SY, Dunn IF, Firestein R, Gupta P, Wardwell L, Repich K, Schinzel AC, Wittner B, Silver SJ, Root DE, Boehm JS, Ramaswamy S, Lander ES, Hahn WC. CK1epsilon is required for breast cancers dependent on beta-catenin activity. PLoS One. 2010; 5: e8979.

15. Lin SH, Lin YM, Yeh CM, Chen CJ, Chen MW, Hung HF, Yeh KT, Yang SF. Casein kinase 1 epsilon expression predicts poorer prognosis in low T-stage oral cancer patients. Int J Mol Sci. 2014; 15: 2876-2891.

16. Fuja TJ, Lin F, Osann KE, Bryant PJ. Somatic mutations and altered expression of the candidate tumor suppressors CSNK1 epsilon, DLG1, and EDD/hHYD in mammary ductal carcinoma. Cancer Res. 2004; 64: 942-951.

17. Richter J, Ullah K, Xu P, Alscher V, Blatz A, Peifer C, Halekotte J, Leban J, Vitt D, Holzmann K, Bakulev V, Pinna LA, Henne-Bruns D, Hillenbrand A, Kornmann M, Leithauser F et al. Effects of altered expression and activity levels of CK1delta and varepsilon on tumor growth and survival of colorectal cancer patients. Int J Cancer. 2014.

18. Brockschmidt $\mathrm{C}$, Hirner $\mathrm{H}$, Huber $\mathrm{N}$, Eismann $\mathrm{T}$, Hillenbrand A, Giamas G, Radunsky B, Ammerpohl O, Bohm B, Henne-Bruns D, Kalthoff H, Leithauser F, Trauzold A, Knippschild U. Anti-apoptotic and growthstimulatory functions of CK1 delta and epsilon in ductal adenocarcinoma of the pancreas are inhibited by IC261 in vitro and in vivo. Gut. 2008; 57: 799-806.

19. Sakanaka C, Leong P, Xu L, Harrison SD, Williams LT. Casein kinase iepsilon in the wnt pathway: regulation of beta-catenin function. Proc Natl Acad Sci U S A. 1999; 96: 12548-12552.

20. Kishida M, Hino S, Michiue T, Yamamoto H, Kishida S, Fukui A, Asashima M, Kikuchi A. Synergistic activation of the Wnt signaling pathway by Dvl and casein kinase Iepsilon. J Biol Chem. 2001; 276: 33147-33155.

21. Foldynova-Trantirkova S, Sekyrova P, Tmejova K, Brumovska E, Bernatik O, Blankenfeldt W, Krejci P, Kozubik A, Dolezal T, Trantirek L, Bryja V. Breast cancerspecific mutations in CK1epsilon inhibit Wnt/beta-catenin and activate the Wnt/Rac1/JNK and NFAT pathways to decrease cell adhesion and promote cell migration. Breast Cancer Res. 2010; 12: R30.

22. Bryja V, Schambony A, Cajanek L, Dominguez I, Arenas E, Schulte G. Beta-arrestin and casein kinase $1 / 2$ define distinct branches of non-canonical WNT signalling pathways. EMBO Rep. 2008; 9: 1244-1250.

23. Bryja V, Schulte G, Rawal N, Grahn A, Arenas E. Wnt5a induces Dishevelled phosphorylation and dopaminergic differentiation via a CK1-dependent mechanism. J Cell Sci. 2007; 120: 586-595.

24. Katoh M, Katoh M. WNT signaling pathway and stem cell signaling network. Clin Cancer Res. 2007; 13: 4042-4045.

25. Collu GM, Hidalgo-Sastre A, Brennan K. Wnt-Notch 
signalling crosstalk in development and disease. Cell Mol Life Sci. 2014; 71: 3553-3567.

26. Bogaerts E, Heindryckx F, Vandewynckel YP, Van Grunsven LA, Van Vlierberghe $H$. The roles of transforming growth factor-beta, Wnt, Notch and hypoxia on liver progenitor cells in primary liver tumours (Review). Int J Oncol. 2014; 44: 1015-1022.

27. Yang JY, Hung MC. A new fork for clinical application: targeting forkhead transcription factors in cancer. Clin Cancer Res. 2009; 15: 752-757.

28. Zanella F, Link W, Carnero A. Understanding FOXO, new views on old transcription factors. Curr Cancer Drug Targets. 2010; 10: 135-146.

29. Shin S, Wolgamott L, Roux PP, Yoon SO. Casein kinase 1epsilon promotes cell proliferation by regulating mRNA translation. Cancer Res. 2014; 74: 201-211.

30. Breast. AJCC Cancer Staging Manual, vol. 7th ed,. New York, NY: Springer; 2009.

31. Perez M, Praena-Fernandez JM, Felipe-Abrio B, LopezGarcia MA, Lucena-Cacace A, Garcia A, Lleonart M, Roncador G, Marin JJ, Carnero A. MAP17 and SGLT1 protein expression levels as prognostic markers for cervical tumor patient survival. PLoS ONE. 2013; 8: e56169.

32. Molina-Pinelo S, Ferrer I, Blanco-Aparicio C, Peregrino S, Pastor MD, Alvarez-Vega J, Suarez R, Verge M, Marin JJ, Hernandez-Losa J, Ramon y Cajal S, Paz-Ares L, Carnero A. Down-regulation of spinophilin in lung tumours contributes to tumourigenesis. J Pathol. 2011; 225: 73-82.

33. Link W, Rosado A, Fominaya J, Thomas JE, Carnero A. Membrane localization of all class I PI 3-kinase isoforms suppresses c-Myc-induced apoptosis in Rat1 fibroblasts via Akt. J Cell Biochem. 2005; 95: 979-989.

34. Ferrer I, Blanco-Aparicio C, Peregrina S, Canamero M, Fominaya J, Cecilia Y, Lleonart M, Hernandez-Losa J, Ramon y Cajal S, Carnero A. Spinophilin acts as a tumor suppressor by regulating $\mathrm{Rb}$ phosphorylation. Cell Cycle. 2011; 10: 2751-2762. 